\title{
Research on Fire Resistance of Ultra-High-Performance Concrete
}

\author{
Hao-wen Ye, ${ }^{1}$ Nai-qian Feng, ${ }^{2}$ Yan Ling-hu, ${ }^{1}$ Zhi-wei Ran, ${ }^{1}$ Li-xun Lin, ${ }^{1}$ \\ Shi-kun Qi, ${ }^{1}$ and Yi Dong ${ }^{1}$ \\ ${ }^{1}$ Technology Department, China Construction Fourth Engineering Division Corporation Ltd., Guangzhou 510665, China \\ ${ }^{2}$ Senior Scientists Association, Tsinghua University, Beijing 100084, China
}

Correspondence should be addressed to Yan Ling-hu, linghuyan9@hotmail.com

Received 13 December 2011; Accepted 11 February 2012

Academic Editor: Gai-Fei Peng

Copyright () 2012 Hao-wen Ye et al. This is an open access article distributed under the Creative Commons Attribution License, which permits unrestricted use, distribution, and reproduction in any medium, provided the original work is properly cited.

Fire resistance of ultrahigh-performance concrete was measured under different temperatures and loadings. C120 concrete was prepared with $1 \mathrm{~kg} / \mathrm{m}^{3}$ organic fiber and C120 concrete with $2 \mathrm{~kg} / \mathrm{m}^{3}$ organic fiber and tested under loading at $30 \%$ ultimate strength when exposed to high temperatures of $200^{\circ} \mathrm{C}, 300^{\circ} \mathrm{C}$, and $400^{\circ} \mathrm{C}$, respectively.

\section{Introduction}

At present, the research on the fire resistance of ultra-highperformance concrete equal to or greater than C100 has yet prevailed. However, concrete buildings usually get badly damaged in fire (Figures 1 and 2), causing high life and property losses, let alone environmental pollution [1].

We conducted thorough research on the fire resistancy of ultra-high-performance concrete and fortunately discovered regularity in it and came up with some countermeasures, making agreeable contribution to the study of this issue.

\section{Raw Materials}

(1) Cement: Nanjing Xiaoyetian P II 52.5.

(2) Microballoon, made in Kunming, average diameter $\leqq 1 \mu \mathrm{m}$ and superficial area $12000 \mathrm{~cm}^{2} / \mathrm{g}$.

(3) Ganister sand, from Zhunyi, Guizhou; superficial area $20000 \mathrm{~cm}^{2} / \mathrm{g}[2]$.

(4) Mineral Powder (ultra fine), from Jiangmen, Guangdong, superficial area $8500 \mathrm{~cm}^{2} / \mathrm{g}$.

(5) Fine aggregate, sea sand from Shenzhen, desalted, FM $2.6 \sim 2.8$.

(6) Coarse aggregate, macadam from Shenzhen, 5-10, $10-20 \mathrm{~mm}$ in diameter.
(7) Water reducer, BASF polycarboxylic acid, solid content: $40 \%$; self-made naphthalene-sulfamate water reducer.

(8) Polypropylene fiber, Grace $19 \mathrm{~mm}$ long fiber [3].

\section{Mix Proportions of Ultra-High-Performance Concrete}

Based on previous test results, we prepared the fire-resistant C120 concrete by proportions found in Table 1.

Finished test pieces were in 3 sizes: $100 \times 100 \times 300 \mathrm{~mm}$, $\Phi 100 \times 150 \mathrm{~mm}$, and $\Phi 100 \times 300 \mathrm{~mm}$, as in Figures 3, 4, and 5.

\section{Equipment}

(1) Heating: we designed 3 heating apparatus and assigned a workshop to manufacture them for us. They came out as in Figures 6, 7, and 8.

(2) Loading: $2000 \mathrm{KN}$ digital press machine.

\section{Research Approach}

To simulate the situation of ultra-high-performance concrete under pressure in case of fire, we came up with the following research plan. 
Table 1: Mix Proportions.

\begin{tabular}{lccccccccc}
\hline $\begin{array}{l}\text { Ratio of water to } \\
\text { plastic }\end{array}$ & Water & Cement & $\begin{array}{l}\text { Microballoon + ganister } \\
\text { sand + mineral powder }\end{array}$ & Sea Sand & \multicolumn{2}{c}{ Coarse aggregate } & Additive & $\begin{array}{c}\text { Fiber content } \\
\left(\mathrm{kg} / \mathrm{m}^{3}\right)\end{array}$ & Steel bars \\
\hline 0.174 & 122 & 550 & 150 & 750 & 285 & 665 & 1.3 & 0 & No \\
0.174 & 122 & 550 & 150 & 750 & 285 & 665 & 1.4 & 1 \\
0.174 & 122 & 550 & 150 & 750 & 285 & 665 & 2.17 & 2 & No \\
0.18 & 135 & 500 & 250 & 700 & 300 & 700 & 1.3 & 0 & No \\
\hline
\end{tabular}

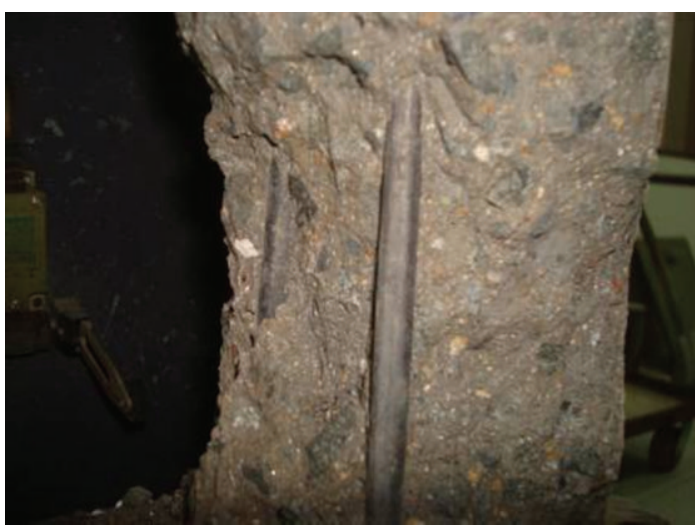

Figure 1

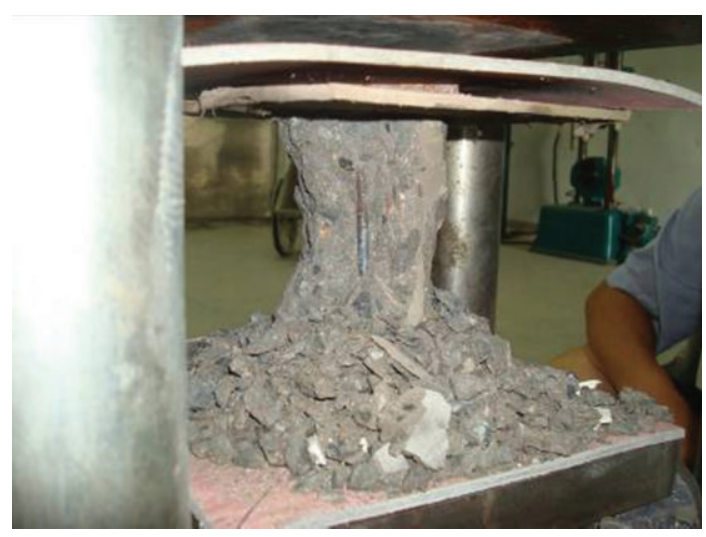

Figure 2

(1) Take one test piece out of each type, perform axial compressive strength test on them, and write down the numbers.

(2) When the axial compressive strength values of each type of test pieces are obtained, set $30 \%$ of each value as the constant loading strength for the certain type.

(3) Put the test pieces onto the press machine and keep adding pressure until the constant loading strength is reached.

(4) While maintaining the pressure, heat the test piece with suitable heating jacket to $200^{\circ} \mathrm{C}, 300^{\circ} \mathrm{C}$, and $400^{\circ} \mathrm{C}$ separately. Keep the heating period within 20 to 30 minutes, once the required temperature is reached, maintain the temperature for 30 to 40

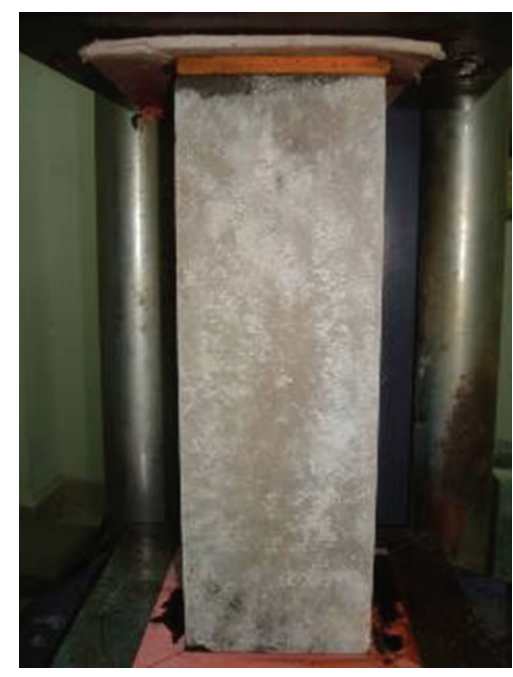

Figure 3

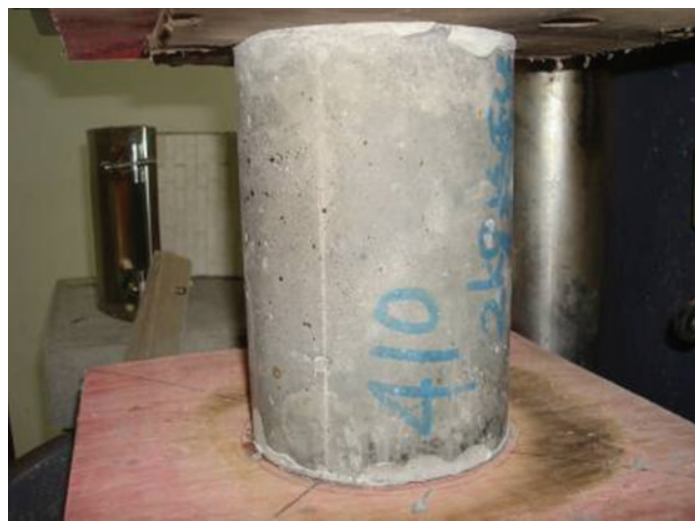

Figure 4

minutes to let the heat spread evenly to every part of the test piece [4].

(5) As soon as the temperature-maintaining time has passed, remove the heating jacket and scrutinize and record any change on the surface. This step must be carried out quickly, for the heat escapes once the heating jacket is removed. 


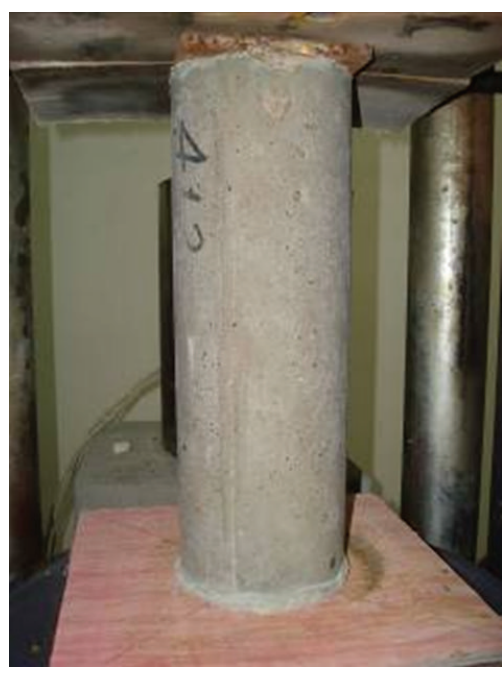

Figure 5

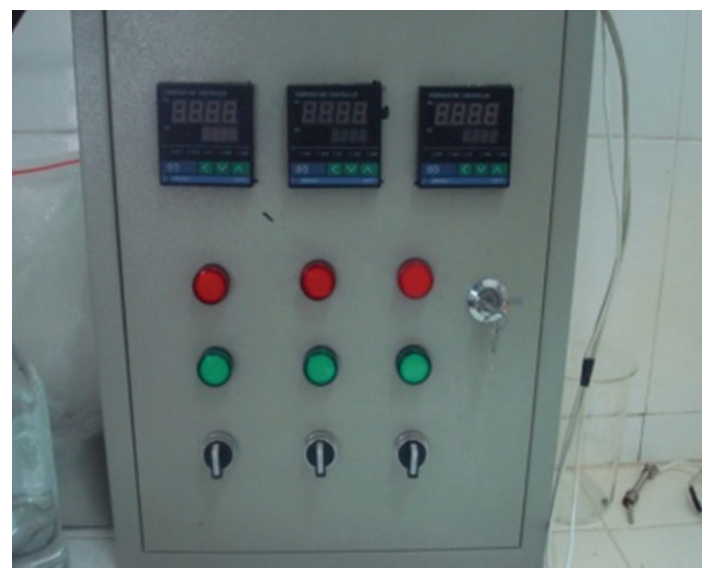

Figure 6: Control cabinet.

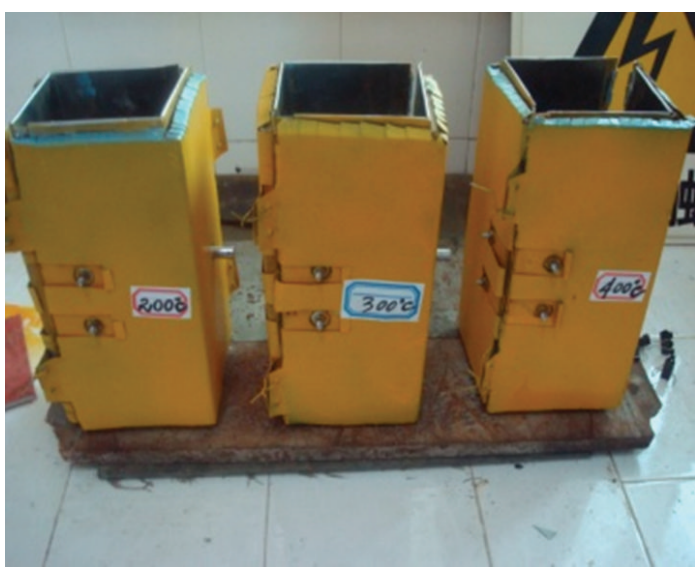

Figure 7: Prismatic heating jacket.

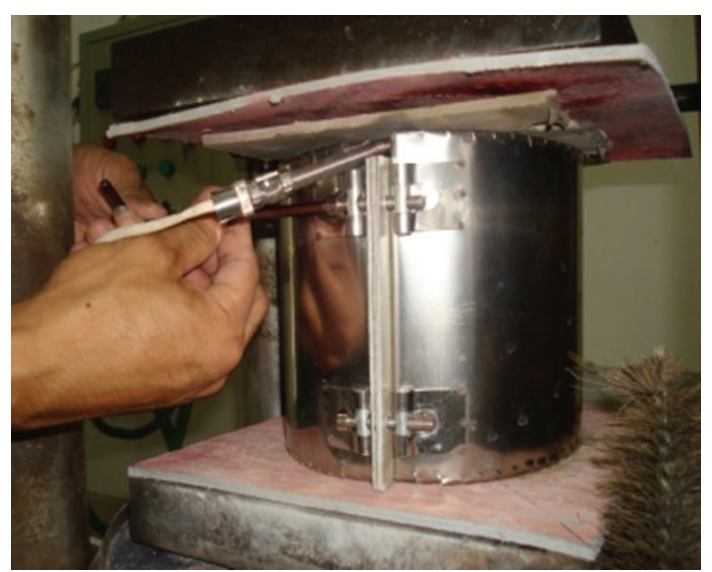

FIGURE 8: Cylindrical heating jacket.

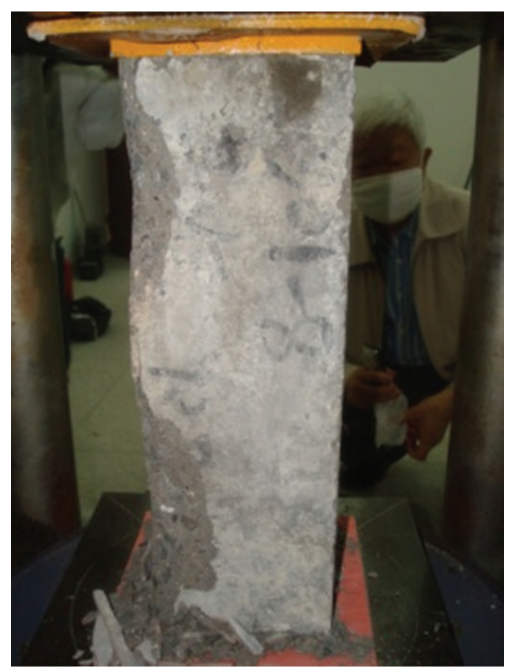

Figure 9

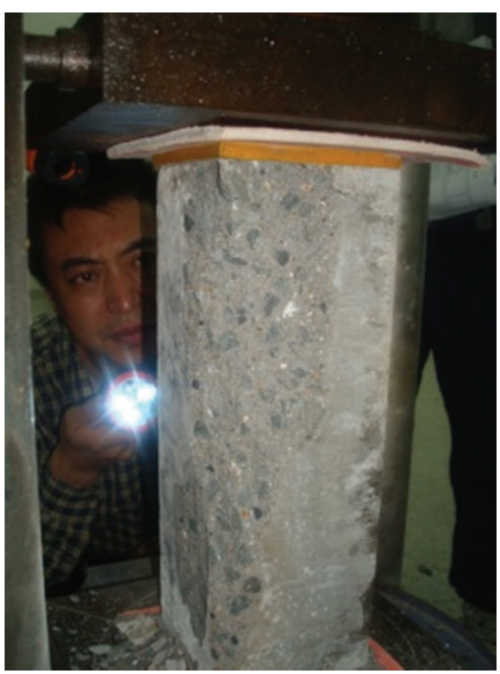

FIGURE 10 


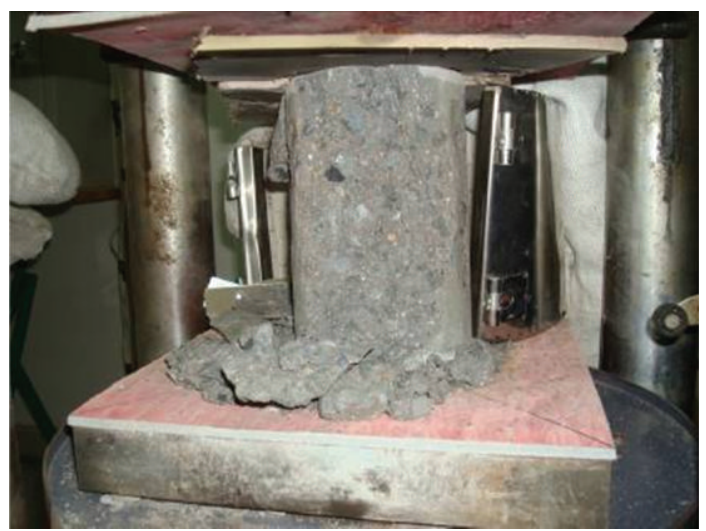

FIgURe 11

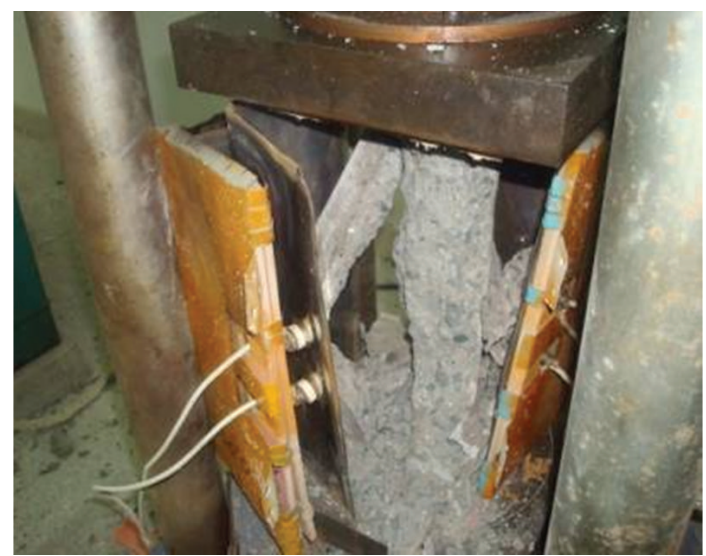

FIgURE 12

\section{Results and Discussion [5]}

\subsection{Basic Test Piece}

(1) Figure 9 features basic test-pieces condition after undergoing constant loading pressure and being heated to $200^{\circ} \mathrm{C}$. We could see from the figure that the concrete on the surface, especially the corners, was flaking away; there were minor cracks everywhere, suggesting cracking was the main reason why the concrete flaked away under the influence of pressure and heat.

(2) Figures 10 and 11 feature basic test-pieces condition after undergoing constant loading pressure and being heated to $300^{\circ} \mathrm{C}$. During the process, the test piece endured dozens of crackings, which led to massive concrete flaking away on the surface; cylindrical test piece even exploded while pressure mounted and got more seriously damaged.

(3) Figure 12 features basic test-pieces condition after undergoing constant loading pressure and being heated to $400^{\circ} \mathrm{C}$. Test piece cracked numerous times during the process of heating, and it exploded while the warmth was being maintained. After all these

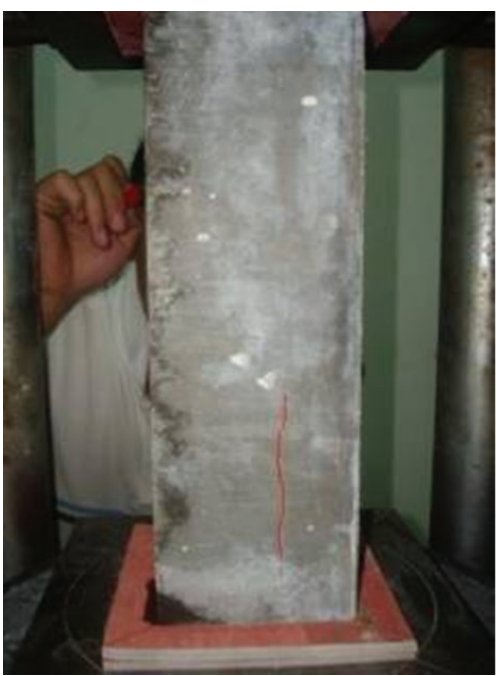

FIgURe 13

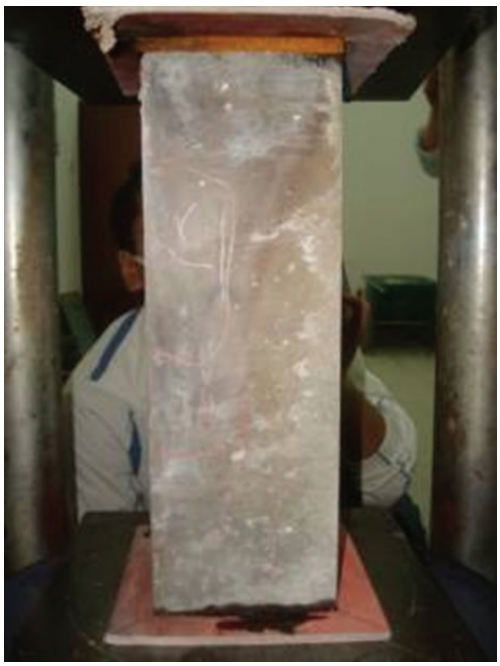

Figure 14

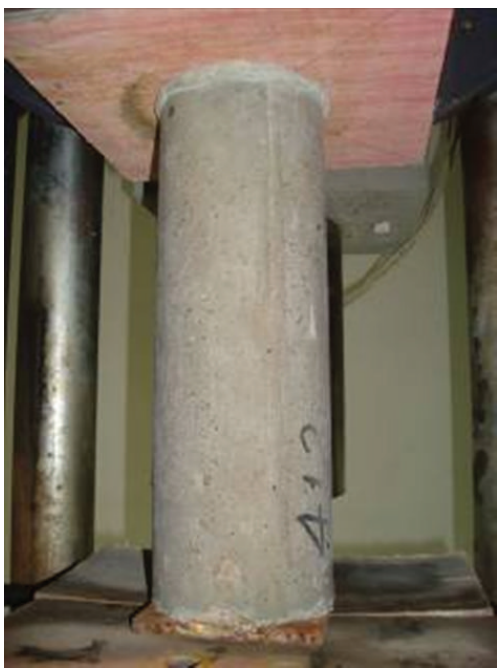

Figure 15 


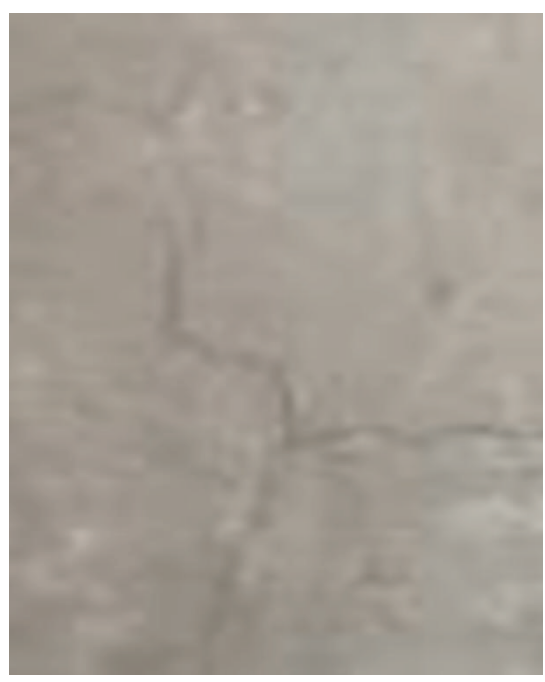

FIgURe 16

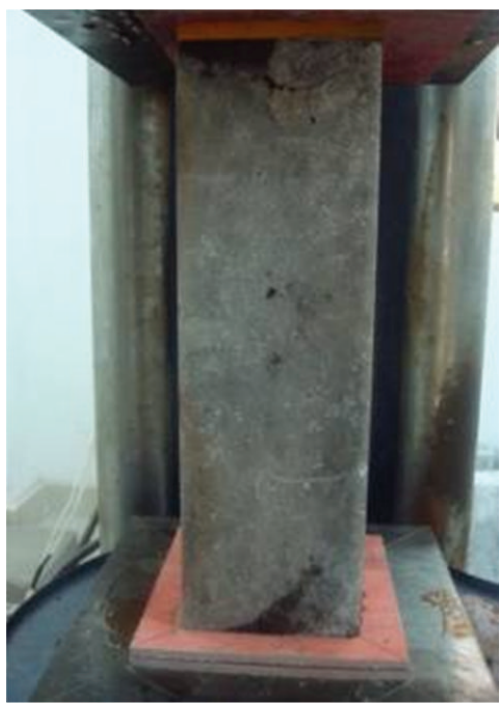

FIGURE 17

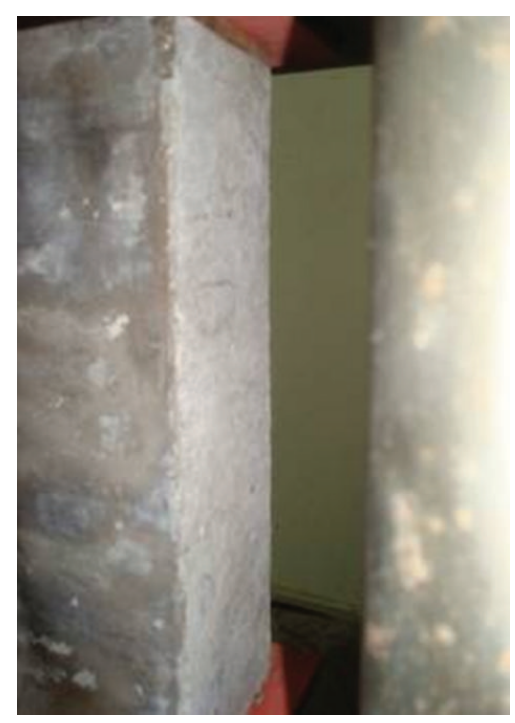

FIGURE 18

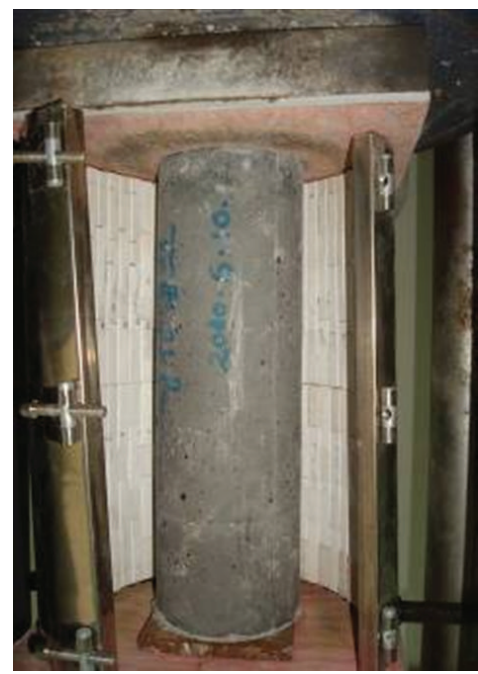

FIgURe 19 ordeals, the test piece was too wrecked to undertake any pressure.

\subsection{Specimen Observations with $1 \mathrm{Kg} / \mathrm{m}^{3}$ Polypropylene Fiber}

(1) Figure 13 features the condition of test piece with $1 \mathrm{Kg} / \mathrm{m}^{3}$ polypropylene fiber after undergoing loading pressure and being heated to $200^{\circ} \mathrm{C}$. It looks quite intact, only few minor cracks can be seen in the figure.

(2) Figures 14 and 15 feature the condition of test piece with $1 \mathrm{Kg} / \mathrm{m}^{3}$ polypropylene fiber after undergoing loading pressure and being heated to $300^{\circ} \mathrm{C}$. Cracks seen in the figures were caused by sudden temperature change after the heating jacket was removed; during heating and loading processes, the test piece was largely intact. Prismatic and cylindrical test pieces showed no difference in this test.

(3) Figure 16 features the condition of test piece with $1 \mathrm{Kg} / \mathrm{m}^{3}$ polypropylene fiber after undergoing loading pressure and being heated to $400^{\circ} \mathrm{C}$. We saw no major cracks but minor ones on the surface of the test piece. In addition, a great number of shallow cracks were also found.

\subsection{Specimen Observations with $2 \mathrm{Kg} / \mathrm{m}^{3}$ Polypropylene Fiber}

(1) Figures 17, 18, and 19 feature the condition of test piece with $2 \mathrm{Kg} / \mathrm{m}^{3}$ polypropylene fiber after undergoing loading pressure and being heated to $200^{\circ} \mathrm{C}$ and $300^{\circ} \mathrm{C}$. After the tests, it appeared nice and sound. 


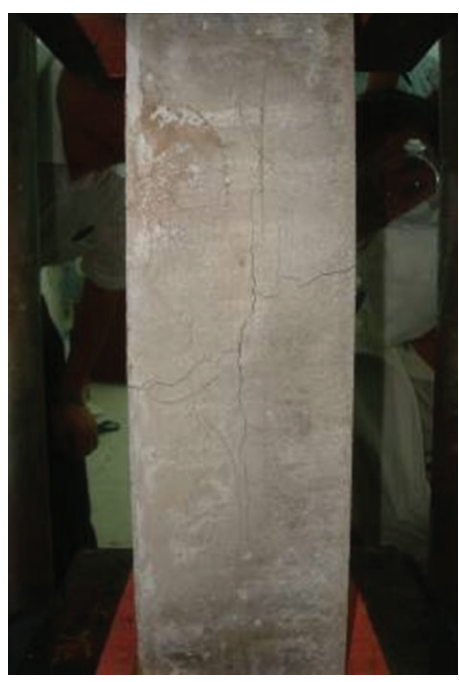

FIgURE 20

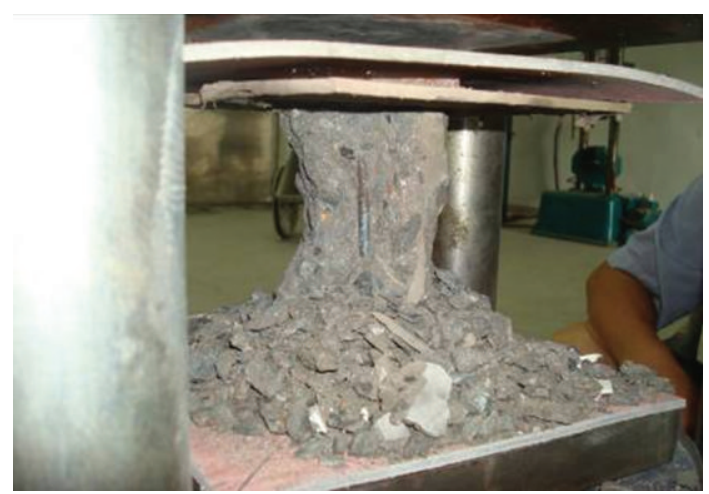

FIgURe 21

(2) Figure 20 features the condition of test piece with $2 \mathrm{Kg} / \mathrm{m}^{3}$ polypropylene fiber after undergoing loading pressure and being heated to $400^{\circ} \mathrm{C}$. It did not explode in such temperature, but minor cracks still appeared.

6.4. Reinforced Concrete Specimen Observations. Put steel bars into C120 concrete and observe how it changes during the test. Figures 21 and 22 feature the condition of reinforced concrete test-pieces sized $\Phi 100 \times 150 \mathrm{~mm}$ and $\Phi 100 \times$ $300 \mathrm{~mm}$ after undergoing loading pressure and being heated to $300^{\circ} \mathrm{C}$. Test pieces exploded during test, not only the concrete fell off into pieces, but also the steel bars were partly exposed in the air.

\section{Analysis}

By comparing and analyzing the test results, the research group made the following findings concerning the possible changes of ultra-high-performance concrete in case of fire.

(1) The temperature to which the test pieces were heated has been a main factor in ultra-high-performance concrete changes. This particularly applied to basic test piece, which

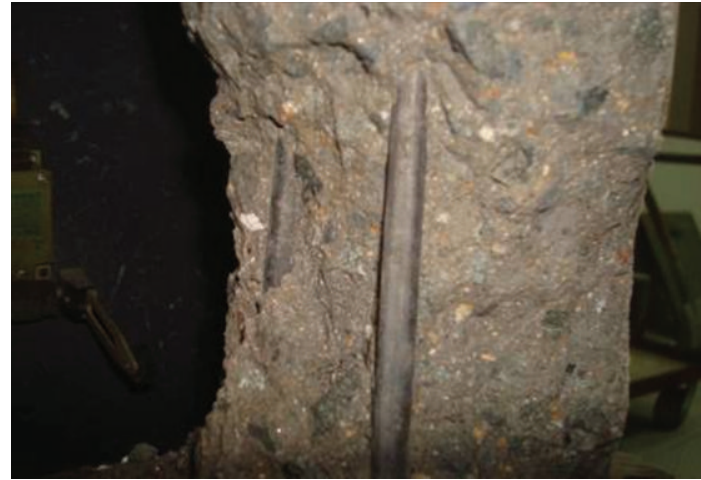

FIGURE 22

cracked many times and more severely at $300^{\circ} \mathrm{C}$ than at $200^{\circ} \mathrm{C}$ and eventually exploded at $400^{\circ} \mathrm{C}$, forcing the test to get aborted.

(2) At $300^{\circ} \mathrm{C}$, reinforced concrete test pieces were more vulnerable to heat than others. Basic test pieces suffered moderate flake-away while reinforced concrete ones broke into pieces, revealing steel bars.

This phenomenon resulted from the fact that steel bars swelled when heated. For basic test pieces, the crackings were caused by the stress released from their own thermal expansion; for reinforced concrete test pieces, they underwent not only stress from its own thermal expansion but also the thermal expansion of the steel bars. It is not hard to explain why the latter broke from the inside out [6].

(3) Certain amount of polypropylene fiber would noticeably enhance ultra high-performance concrete's fireresistance. Heated to $200 \sim 300^{\circ} \mathrm{C}$, test pieces with fiber hardly showed changes; test pieces with $2 \mathrm{~kg} / \mathrm{m}^{2}$ fiber stayed intact at moderately high temperature, even at $400 \sim 500^{\circ} \mathrm{C}$, they only chapped a little.

This can be explained this way: the polypropylene fiber mixed into concrete test piece melts in the heat, creating steam vessels throughout the whole test piece. These vessels not only help drain or ventilate the liquid and vapor within the body, but also make room for thermal expansion, which reduces its chance of cracking and exploding [7].

This finding coincides with the popular vapor pressure theory in the explanation of high-performance concrete's cracking and exploding. According to vapor pressure theory, the water in concrete turns into vapor when the temperature goes up (e.g., in fire), if the vapor cannot escape in time, pressure will be created inside the concrete body, when the internal pressure accumulates to some degree, explosion happens [8]. Polypropylene fibers melt in the heat, providing ventilation for liquid and vapor, thus they prevent concrete from cracking and exploding.

\section{Conclusions}

Ultra-high-performance concrete is an artificially synthesized material low in water-cement ratio and high in strength, density, impermeability, and brittleness. These traits make it easy to crack in case of fire, which results in 
reduction in strength. Adding polypropylene fibers not only helps enhance concrete's strength and elasticity, but also provides ventilating vessels when the surrounding temperature rises. With these merits, ultra-high-performance concrete with fibers is able to tolerate heat and pressure for a relatively long time without getting seriously damaged, thus making time for firefighters to save people's lives and their properties $[9,10]$.

\section{References}

[1] A. M. Neville, Properties of Concrete, Longman, Harlow, UK, 1995.

[2] C. Y. N. Sammy, P. Gai-Fei, and A. Mike, "Fire behavior of high performance concrete made with silica fume at different moisture contents," ACI Materials Journal, vol. 96, no. 3, pp. 405-409, 1999.

[3] G. Peng, W. Yang, J. Zhao, Y. Liu, S. Bian, and L. Zhao, "Explosive spalling and residual mechanical properties of fiber-toughened high-performance concrete subjected to high temperatures," Cement and Concrete Research, vol. 36, no. 4, pp. 723-727, 2006.

[4] D. Gawin, C. E. Majorana, F. Pesavento, and B. A. Schrefler, "A new approach in the hygro-thermo-mechanical analysis of concrete at high temperature," in Proceedings of the Eighth International Conference on Computing in Civil and Building Engineering, vol. 1, pp. 457-464, 2000.

[5] U. Schneider, U. Diederichs, and J. Horvath, "Verhalten von ultrahochfesten betonen (UHPC) unter brandbeanspruchung (behaviour of ultra high performance concrete (UHPC) under fire exposure)," Beton-und Stahlbetonbau, vol. 98, no. 7, pp. 408-417, 2003.

[6] P. Bamonte, P. G. Gambarova, and A. Meda, "Today's concretes exposed to fire-test results and sectional analysis," Structural Concrete, vol. 9, no. 1, pp. 19-29, 2008.

[7] G. A. Khoury, C. E. Majorana, F. Pesavento, and B. A. Schrefler, "Modelling of heated concrete," Magazine of Concrete Research, vol. 54, no. 2, pp. 77-101, 2002.

[8] C. E. Majorana and F. Pesavento, "Damage and spalling in HP and UHF concrete at high temperature," in Damage and Fracture Mechanics VI: Computer Aided Assessment and Control, vol. 6 of Structures and Materials, pp. 105-117, 2000.

[9] H. S. Muller and M. Haist, "Bauen im bestand-markt der zukunft-innovative betonbautechniken-potenziale fur die vorfertigung? (building in the context of existing structuresa future market-innovative concrete construction methodsopportunities for prefabrication?)," Betonwerk und FertigteilTechnik/Concrete Plant and Precast Technology, vol. 74, no. 2, pp. 144-145, 2008.

[10] K. Habel, M. Viviani, E. Denarié, and E. Brühwiler, "Development of the mechanical properties of an ultra-high performance fiber reinforced concrete (UHPFRC)," Cement and Concrete Research, vol. 36, no. 7, pp. 1362-1370, 2006. 

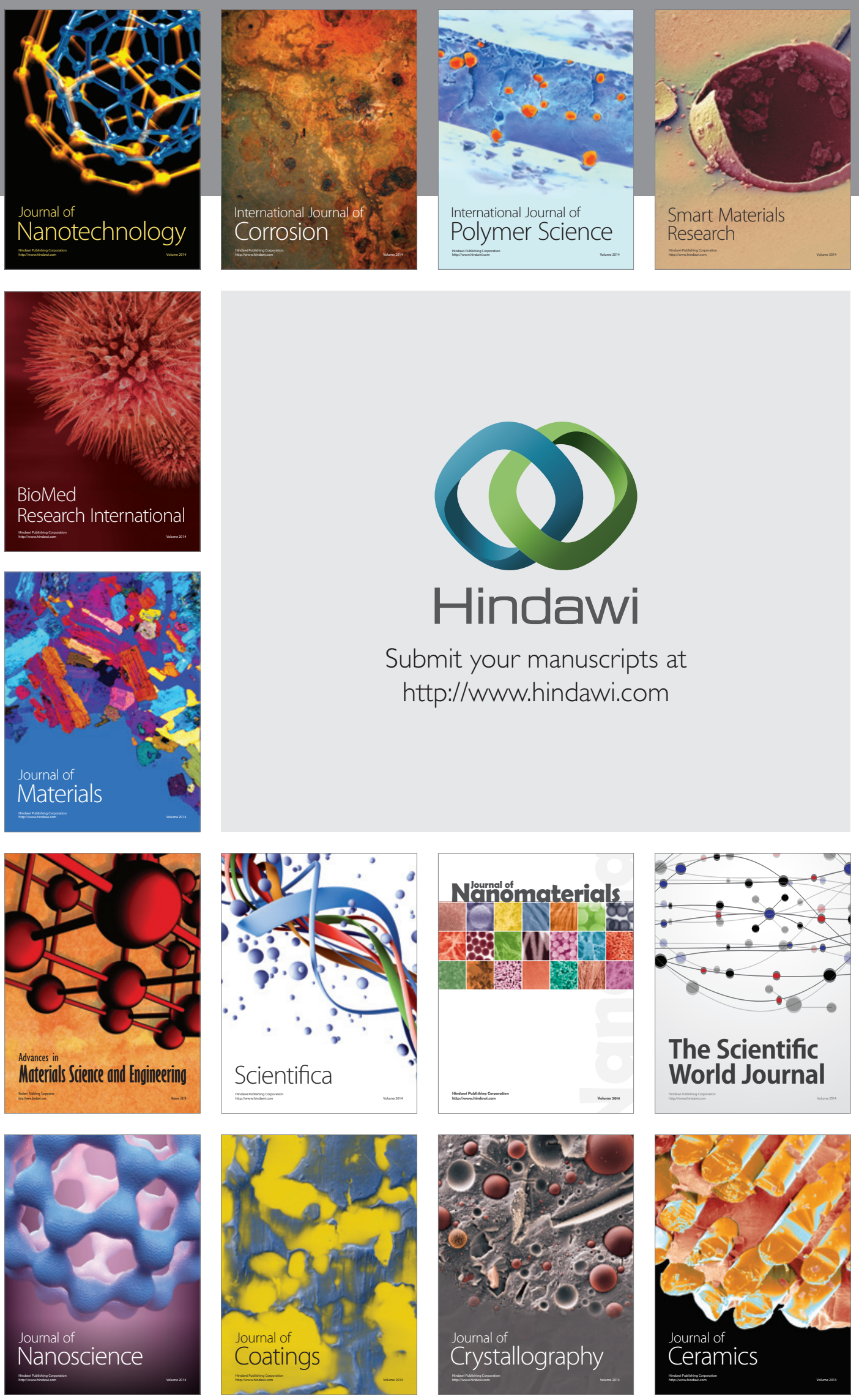

The Scientific World Journal

Submit your manuscripts at

http://www.hindawi.com

\section{World Journal}

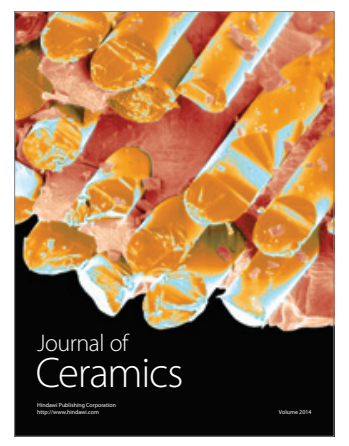

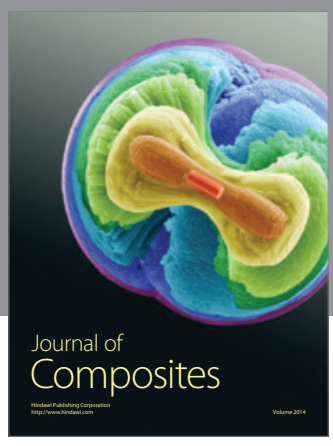
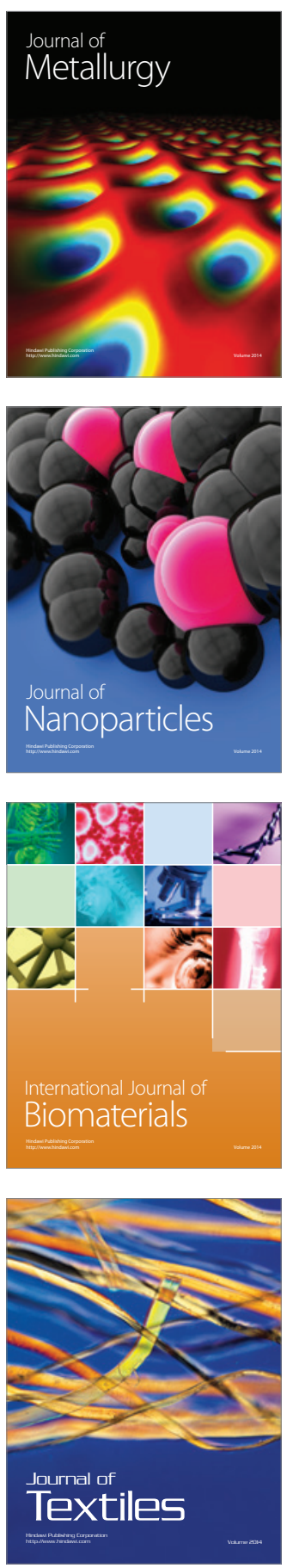